\title{
Seroprevalence of Zika virus among blood donors before the epidemic in Barranquilla, Colombia, 2015-2016.
}

\author{
BRAYAN BAYONA-PACHECO ${ }^{1}$, JORGE ACOSTA-REYES ${ }^{2}$, EDGAR NAVARRO ${ }^{2}$, \\ HOMERO SAN-JUAN ${ }^{1}$, JOHAN BULA ${ }^{3}$ and HERNANDO BAQUERO ${ }^{1}$ \\ ${ }^{1}$ Departamento de Medicina, División Ciencias de la Salud, Universidad del Norte, Km \\ 5, vía Puerto Colombia, Área Metropolitana de Barranquilla, Colombia \\ ${ }^{2}$ Departamento de Salud Pública, División Ciencias de la Salud, Universidad del Norte, \\ Km 5, vía Puerto Colombia, Área Metropolitana de Barranquilla, Colombia \\ ${ }^{3}$ Banco Nacional de Sangre, Carrera, 50 \# 80-192, Barranquilla, Atlántico, Colombia \\ Manuscript received on August 21, 2018; accepted for publication on November 9, 2018
}

\begin{abstract}
How to cite: BAYONA-PACHECO B, ACOSTA-REYES J, NAVARRO E, SAN-JUAN H, BULA J AND BAQUERO H. 2019. Seroprevalence of Zika virus among blood donors before the epidemic in Barranquilla, Colombia, 20152016. An Acad Bras Cienc 91: e20180860. DOI. 10.1590/0001-3765201920180860.
\end{abstract}

\begin{abstract}
The first cases of Zika virus infection in Colombia were reported and confirmed in October 2015. The objective of the study was estimate the seroprevalence of ZIKV infection during the preepidemic phase in Barranquilla, Colombia, and demonstrate the presence of virus before the Colombian Ministry of Health confirmed the first case. We conducted a descriptive study of the seroprevalence of Zika virus in 390 samples obtained from a blood bank located in Barranquilla, Colombia - a city endemic for dengue, and with a recent history of a Chikungunya disease epidemic. The serum pools were tested using Euroimmun ZIKV ELISA kit. Seroprevalence of Zika virus IgG were: May 2015: 0\%, June and July 2015: $2.62 \%(95 \% \mathrm{CI}=0.28-12.13)$ and August 2015: 5.35\% (95\% CI $=1.74-16.74)$. This brings to our attention the need for extending the surveillance period of this virus in order to adequately assess its teratogenic effects.
\end{abstract}

Key words: Zika virus, seroprevalence, pre-epidemic dates, pregnant women.

\section{INTRODUCTION}

On May $7^{\text {th }} 2015$, the World Health Organization (WHO) and the Pan American Health Organization (PAHO) issued an epidemiological alert to all member states regarding ZIKV infection. This alert recommended countries at risk to establish and maintain protocols for detecting and confirming ZIKV infection as well as for adequately treating the infected patients. Furthermore, it

Correspondence to: Brayan Bayona-Pacheco

E-mail: bbayona@uninorte.edu.co

ORCid: https://orcid.org/0000-0002-8908-1761 suggested countries to implement an effective risk communication strategy, to reduce the presence of the mosquito that transmits the virus, and to take precautions against any mosquito bites (Pan American Health Organization. PAHO/ World Health Organization. WHO 2015). In October 2015, the Colombian Ministry of Health confirmed the first case of ZIKV infection in the State of Bolivar (Pacheco et al. 2016, World Health Organization 2015), and issued instructions for public health surveillance, clinical care, and prevention and control in the face of the arrival of ZIKV to the country (Ministry of Health 2015) . 
ZIKV infections were not commonly known worldwide to the majority of physicians, public health professionals, and policy makers, due to reported cases being quite low and also because previously reported ZIKV infection were usually mild. The non-specific symptomatology of ZIKV infections, together with its prevalence in areas where other arboviruses commonly circulate, render it difficult to diagnose (Brasil et al. 2016, Kelser 2016, Malone et al. 2016, World Health Organization 2016). For example, ZIKV infections present very similar clinical symptoms to those of dengue, and can occur in individuals co-infected with the dengue virus. The fact that only one in every five individuals infected by the ZIKV develops symptomatology means that public health prevention, and epidemiological surveillance can become complicated (Brooks et al. 2016, Dasgupta et al. 2016, Pacheco et al. 2016, Russell et al. 2016, Sikka et al. 2016). The incidence of ZIKV infections during the epidemic phase was reported to be 377.7 per 100,000 inhabitants.

Before August $9^{\text {th }} 2015$, the nationwide surveillance system did not consistently monitor ZIKV (National Institute of Health Colombia 2015). However, after the first cluster of laboratory confirmed cases in October 2015, the ZIKV outbreak extended throughout all areas in Colombia.

Barranquilla, is located on the Caribbean coast of Colombia just 100 kilometers from the town where the first local ZIKV infections were confirmed. During the epidemiological surveillance period, Barranquilla reported the second largest number of affected pregnant women, and the second largest number of cases of neurological syndromes among patients who had previously experienced typical ZIKV infection symptoms (Pacheco et al. 2016).

Blood bank donor samples have been used by various authors to estimate the seroprevalence of infectious diseases. This measurement provides information regarding the magnitude of the circulating pathogen, and the date when the first cases of the epidemic appear (Contreras et al. 1999, Gallian et al. 2017, Noubiap et al. 2013, Veguilla et al. 2016, Yamashiro et al. 2004.). It is important to try and determine the moment in which ZIKV began circulating in a certain area in order to properly define the exposure period. In this way, risk estimates for known adverse outcomes after ZIKV exposure such as microcephaly and Guillain-Barre syndrome can be determined, and the expected number of infected individuals during a certain period can be predicted (Reefhuis et al. 2016). Furthermore, knowing the gestational timing of maternal ZIKV infection is critical because the effect that this infection has on the fetus, as well as on infant outcomes, is variable. Moreover, the epidemic curve currently available for this disease is based on both suspected cases that have been determined primarily based on clinical presentation and laboratory confirmed ZIKV.

We conducted a descriptive study of blood bank samples taken from May 2015 to August 2015 to estimate the seroprevalence of ZIKV infection during the pre-epidemic phase in Barranquilla, Colombia.

\section{MATERIALS AND METHODS}

\section{SAMPLES COLLECTION}

This study was based on 390 donated blood samples (whole blood donors, with signature of informed consent and approval of the ethics committee Evaluation report 157 of May $25^{\text {th }}, 2017$. All data were handled confidentially and anonymously) from the National Blood Bank in Barranquilla, Colombia during the pre-epidemic ZIKV period (May $6^{\text {th }}$ to August $31^{\text {st }}, 2015$ ). We employed a pooled method in which samples from each week were pooled for conducting the seroprevalence analysis. This strategy assumes that the estimated prevalence obtained from the analysis of pools is similar to that obtained from the analysis of 
individual samples when the actual prevalence is below $30 \%$.

\section{STATISTICAL ANALYSIS}

These estimations of seroprevalence were carried out using the EpiTools epidemiological calculator. We applied the formula for pooled prevalence that is used when employing a fixed pool size and an analytical test with known sensitivity and specificity (Sergeant 2017).

In order to calculate the optimal pool size that is, the number of samples per pool - we used Method 4 of Cowling (Williams 2010). This method is based on an estimated prevalence that takes into account the sensitivity and specificity of the analytical assay. In our case, the Euroimmun ZIKV ELISA kit (Euroimmun, Lübeck, Germany) has a reported sensitivity of $76 \%$ and a specificity of $100 \%$ (Huzly et al. 2016). There is also no cross-reactivity with the dengue virus, even in the presence of high levels of IgG (Steinhagen et al. 2016). A pre-epidemic seroprevalence of ZIKV below $10 \%$ was assumed, and the following was taken into account: a precision of $5 \%$, a confidence level of $95 \%$, a kit sensitivity of $76 \%$, and a kit specificity of $100 \%$. Based on optimal strategies for pooling samples, 390 samples were taken. We then adjusted the number of samples obtained for each pool using William's criteria (Williams 2010). This considers the prevalence at which the number of tests carried out is $25 \%$ less than the number of samples collected. The number of samples per pool was calculated to be 32 for an estimated critical prevalence of $10 \%$. Finally, we used 15 samples per pool because of the moderate sensitivity and high specificity reported for the Euroimmun ZIKV ELISA kit.

\section{SEROLOGIC DIAGNOSIS OF ANTI-ZIKV IgG}

The Euroimmun ZIKV ELISA kit was used to determine the levels of anti-ZIKV IgG in blood donor samples. The serum of each donor was mixed gently by vortex. Then, $20 \mu \mathrm{L}$ of each sample was taken and homogenously mixed in a 1.5 -mL tube. Subsequently, $10 \mu \mathrm{L}$ of each pool was taken for anti-ZIKV IgG detection according to the manufacturer's instructions. Briefly, $10 \mu \mathrm{L}$ of each pool was diluted in $1 \mathrm{~mL}$ of sample buffer, and incubated at $37^{\circ} \mathrm{C}$ during 60 minutes in one well of the ELISA microplate. Afterwards, washes were performed and the peroxidase-labeled anti-human IgG was added for 30 minutes at room temperature. After washing, the substrate was added and incubated for 15 minutes at room temperature. The reaction was stopped by the addition of $0.5 \mathrm{~mol} / \mathrm{L}$ sulfuric acid. Finally, the optical density (OD) was measured at $450 \mathrm{~nm}$ using the automated system BEST 2000 (BIOKIT). Values $<1.1$ were considered to be negative and values $\geq 1.1$ as positive.

\section{RESULTS}

\section{ESTIMATED ZIKV IgG SEROPREVALENCE BY ELISA}

We took 390 samples in total, according to the estimated sample. The samples from May 2015, from June and July 2015, and from August 2015. (Table I). We decided to take more samples in August because it was the month just prior to the reported cases that prompted the government of Colombia to declare a ZIKV state of emergency.

\section{DISCUSSION}

Phylogenetic and molecular analyses of ZIKV have suggested a unique form of introduction into the Americas between May and December 2013. This corresponds to more than 12 months before the detection of ZIKV in Brazil (Brasil et al. 2016, Faria et al. 2016). Our results provide evidence for ZIKV infections even before the dates reported by the INS (National Health Institute) of Colombia (October 2015) (National Institute of Health Colombia 2015) and what was reported by the 
TABLE I

Zika virus seroprevalence among persons randomly recruited from the donated blood samples.

\begin{tabular}{cccc}
\hline TIME & SAMPLES & No POOLS & SEROPREVALENCE \\
\hline May 2015 & 60 & 4 & \% [95\% CI] \\
\hline June and July 2015 & 120 & 8 & $0 \%[0]$ \\
August 2015 & 210 & 14 & $2.62 \%[0.28-12.13]$ \\
\hline
\end{tabular}

groups of Pacheco (Pacheco et al. 2016) and LeónMayorga (León-Mayorga et al. 2017). This was very important given the evidence that newborns exposed to ZIKV during pregnancy should be monitored for possible complications during the postnatal period.

Data regarding the duration or the persistence of IgM antibodies following ZIKV infection is limited. However, IgM antibodies against the West Nile virus, a closely related Flavivirus, have been detected in asymptomatic blood donors at least three months after the blood was given (Prince et al. 2005, 2007, Roehrig et al. 2003). Neutralizing antibodies against ZIKV develop shortly after the IgM antibodies, and consist mainly of IgG antibodies. These latter antibodies generally persist for many years after Flavivirus infections (Poland et al. 1981, Whitehead et al. 2007).

The outbreak of diseases caused by ZIKV peaked in Colombia between the fourth and sixth epidemiological week of 2016 (National Institute of Health Colombia 2017). Up until the eleventh epidemiological week of 2016, 50 cases of live births with microcephaly had been reported. Of these, 41 fulfilled the criteria to be screened for possible maternal ZIKV infection. Based on historical numbers of microcephaly in Colombia, only 30 cases were expected for this epidemiological week (National Institute of Health Colombia 2016). The highest number of cases of microcephaly were reported about 22 to 24 weeks after the peak of ZIKV cases in Colombia (the $4^{\text {th }}$ to $6^{\text {th }}$ epidemiological week of 2016). In addition, the first cases of microcephaly in Colombia were to asymptomatic mothers (Pacheco et al. 2016) which suggests in a greater impact of the our findings.

The results obtained in our study suggest that ZIKV was in circulation before the date reported by the governmental organizations. As such, this means that the period of analysis of newborns with microcephaly or any other congenital central nervous system (CNS) alteration should be retrospectively extended. This is especially true considering that microcephaly at birth is not an essential hallmark of congenital ZIKV syndrome, and that babies with a normal cephalic perimeter at birth may have other CNS abnormalities associated with congenital ZIKV syndrome and might develop microcephaly and other neurological issues later (Van der Linden et al. 2016). In the same way, since a public health vision the children probably exposed in June - August should be evaluated for other problem like hearing and visual problems zika-related.

It is important to recognize that our study penalizes sensitivity in favor of specificity so that the positive pools are truly positive for ZIKV IgGs.

Another interesting aspect regarding to blood banks, is the prevalence of those infectious agents that are routinely monitored in a mandatory fashion. In addition to monitoring agents that cause chronic infections, infectious agents that are characterized by an acute process are also evaluated due to their possible transfusion risk. In fact, ZIKV has a transfusion risk similar to that of the dengue virus (Wiwanitkit and Wiwanitkit 2016). Although 
congenital transmissions are well described, evidence of the risk associated with transfusions (infection and disease) is only preliminary. Nonetheless, ZIKV RNA has been detected in the blood of donors, and cases of transmission by blood products have in fact been reported (BarjasCastro et al. 2016, Jimenez et al. 2017, Marano et al. 2016).

\section{ACKNOWLEDGMENTS}

We would like to thank to the Banco Nacional de Sangre and to the Universidad del Norte, Barranquilla, Colombia.

\section{AUTHOR CONTRIBUTIONS}

$\mathrm{BB}, \mathrm{HB}, \mathrm{HSJ}, \mathrm{EN}$ and JAR wrote the manuscript. $\mathrm{BB}$ conducted the laboratory experiments, and JB provided the patient sera. All authors participated in the research, and read and approved the final version of the manuscript.

\section{REFERENCES}

BARJAS-CASTRO ML ET AL. 2016. Probable TransfusionTransmitted Zika Virus in Brazil. Transfusion 56(7):16841688.

BRASIL P ET AL. 2016. Zika Virus Outbreak in Rio de Janeiro, Brazil: Clinical Characterization, Epidemiological and Virological Aspects. Edited by A. M. Powers. PLOS Neglect Trop D 10(4): e0004636.

BROOKS RB, CARLOS MP, MYERS RA, WHITE MG, BOBO-LENOCI T, APLAN D, BLYTHE D AND FELDMAN KA. 2016. Likely Sexual Transmission of Zika Virus from a Man with No Symptoms of Infection — Maryland, 2016. MMWR. Morbid Mortal W 65(34): 915-916.

CONTRERAS CE, PANCE A, MARCANO N, GONZÁLEZ N AND BIANCO N. 1999. Detection of specific antibodies to plasmodium falciparum in blood bank donors from malaria-endemic and non-endemic areas of Venezuela. Am J Trop Med Hyg 60(6): 948-953.

DASGUPTA S ET AL. 2016. Patterns in Zika Virus Testing and Infection, by Report of Symptoms and Pregnancy Status - United States. MMWR. Morbid Mortal W 65(15): 395-399.
FARIA NR ET AL. 2016. Zika Virus in the Americas: Early Epidemiological and Genetic Findings. Science (New York, N.Y.) 352(6283): 345-349.

GALLIAN P, LEPARC-GOFFART I, PASCALE R, FRANÇOISE M, FLUSIN O, DJOUDI R, CHIARONI J,CHARREL R, TIBERGHIEN P AND DE LAMBALLERIE X. 2017. Epidemiology of Chikungunya Virus Outbreaks in Guadeloupe and Martinique, 2014: An Observational Study in Volunteer Blood Donors. Edited by M. S. Carvalho. PLOS Neglect Trop D 11(1): e0005254.

HUZLY D, INGEBORG H, SCHMIDT-CHANASIT J AND PANNING M. 2016. High Specificity of a Novel Zika Virus ELISA in European Patients after Exposure to Different Flaviviruses. Eurosurveillance 21(16): 30203.

JIMENEZ A, SHAZ BH AND BLOCH EM. 2017. Zika Virus and the Blood Supply: What Do We Know? TransfuS Med Revi 31(1): 1-10.

KELSER EA. 2016. Meet Dengue's Cousin, Zika. Microbes Infect 18(3): 163-166.

LEÓN-MAYORGA Y, BALDASSARRI-ORTEGO LF, NELLEN-HUMMEL H AND HALABE-CHEREM J. 2017. Zika: Un Problema de Salud Pública. Atención Familiar 24(3): 131-135.

MALONE RW ET AL. 2016. Zika virus: medical countermeasure development challenges. Edited by R. C. Kading. PLOS Neglect Trop D 10(3): e0004530.

MARANO G, SIMONETTA P, STEFANIA V, LIUMBRUNO GM AND GRAZZINI G. 2016. Zika virus and the neverending story of emerging pathogens and transfusion medicine. Blood transfusion 14(2): 95-100.

MINISTRY OF HEALTH COLOMBIA. 2015. External circular 0043 ministry of health.

NATIONAL INSTITUTE OF HEALTH COLOMBIA. 2015. Weekly epidemiological bulletin - SE 40.

NATIONAL INSTITUTE OF HEALTH COLOMBIA. 2016. Weekly epidemiological bulletin - SE 11.

NATIONAL INSTITUTE OF HEALTH COLOMBIA. 2017. Weekly epidemiological bulletin - SE 14.

NOUBIAP NJJ, WALBURGA YAJ, NANSSEU NJR, TENE UG AND SIAKA C. 2013. Sero-epidemiology of human immunodeficiency virus, hepatitis B and $C$ viruses, and syphilis infections among first-time blood donors in Edéa, Cameroon. Int J Infect Dis 17(10): e832-837.

PACHECO O ET AL. 2016. Zika virus disease in Colombia preliminary report. New England J Med, p. 1-10.

PAHO - PAN AMERICAN HEALTH ORGANIZATION / WHO - WORLD HEALTH ORGANIZATION. 2015. Epidemiological alert Zika virus infection.

POLAND JD, CALISHER CH, MONATH TP, DOWNS WG AND MURPHY K. 1981. Persistence of neutralizing antibody $30-35$ years after immunization with 17D yellow fever vaccine. B World Health Organ 59(6): 895-900. 
PRINCE HE, TOBLER LH, LAPÉ-NIXON M, FOSTER GA, STRAMER SLAND BUSCH MP. 2005. Development and persistence of West Nile virus-specific immunoglobulin M (IgM), IgA, and IgG in viremic blood donors. J Clin Microbiol 43(9): 4316-4320.

PRINCE HE, TOBLER LH, YEH C, GEFTER N, CUSTER B AND BUSCH MP. 2007. Persistence of West Nile virusspecific antibodies in viremic blood donors. Clin Vaccine Immunol 14(9): 1228-1230.

REEFHUIS J, GILBOA SM, JOHANSSON MA, VALENCIA D, SIMEONE RM, HILLS SL, POLEN K, JAMIESON DJ, PETERSEN L AND HONEIN MA. 2016. Projecting Month of Birth for At-Risk Infants after Zika Virus Disease Outbreaks. EmerG Infect Dis 22(5): 828-832.

ROEHRIG JT, NASH D, MALDIN B, LABOWITZ A, MARTIN DA, LANCIOTTI RS AND CAMPBELL GL. 2003. Persistence of virus-reactive serum immunoglobulin $\mathrm{M}$ antibody in confirmed West Nile virus encephalitis cases. Emerg Infect Dis 9(3): 376-379.

RUSSELL K ET AL. 2016. Update: Interim guidance for the evaluation and management of infants with possible congenital Zika virus infection - United States, August 2016. MMWR. Morbid Mortal W 65(33): 870-878.

SERGEANT ESG. 2017. Epi Tools - EpiTools epidemiological calculators. Ausvet Pty Ltd.

SIKKA V, CHATTU VK, POPLI RK, GALWANKAR SC, KELKAR D, SAWICKI SG, STAWICKI SP AND PAPADIMOS. 2016. The emergence of Zika virus as a global health security threat: a review and a consensus statement of the INDUSEM joint working group (JWG). J Glob Infect Dis 8(1): 3-15.

STEINHAGEN K ET AL. 2016. Serodiagnosis of Zika virus (ZIKV) infections by a novel NS1-based ELISA devoid of cross-reactivity with dengue virus antibodies: a multicohort study of assay performance, 2015 to 2016. Euro surveill 21(50): 30426.

VAN DER LINDEN V ET AL. 2016. Description of 13 infants born during october 2015-january 2016 with congenital zika virus infection without microcephaly at birth - Brazil. MMWR. Morbid Mortal W 65(47): 1343-1348.

VEGUILLA V ET AL. 2016. A Large Proportion of the mexican population remained susceptible to $\mathrm{A}(\mathrm{H} 1 \mathrm{~N} 1)$ pdm09 infection one year after the emergence of 2009 influenza pandemic. Edited by Z. Ye. PloS ONE 11(3): e0150428.

WHITEHEAD SS, BLANEY JE, DURBIN AP AND MURPHY BR. 2007. Prospects for a dengue virus vaccine. Nature Reviews. Microbiology 5(7): 518-528.

WILLIAMS BG. 2010. Optimal Pooling Strategies for Laboratory Testing. arXiv:1007.4903: 1-3.

WIWANITKIT S AND WIWANITKIT V. 2016. Based on the risk of Dengue virus transmission via blood transfusion: what about the risk in case of Zika virus? Asian Pac J Trop Med 9(11): 1123-1124.

WORLD HEALTH ORGANIZATION. 2015. Zika virus infection - Brazil and Colombia. WHO 21 October.

WORLD HEALTH ORGANIZATION. 2016. Zika virus disease. WHO 12 February.

YAMASHIRO T, DISLA M, PETIT A, TAVERAS D, CASTRO-BELLO M, LORA-ORSTE M, VARDEZ S, CESIN AJ, GARCIA B AND NISHIZONO A. 2004. Seroprevalence of $\mathrm{IgG}$ specific for Dengue virus among adults and children in Santo Domingo, Dominican Republic. Am J Trop Med Hyg Aug 71(2): 138-143. 